\title{
Gasification Coupled Chemical Looping Combustion of Coal: A Thermodynamic Process Design Study
}

\author{
Sonali A. Borkhade, Preksha A. Shriwas, and Ganesh R. Kale \\ Chemical Engineering and Process Development Division, National Chemical Laboratory, Pune 411008, India \\ Correspondence should be addressed to Ganesh R. Kale; gr.kale@ncl.res.in
}

Received 28 October 2012; Accepted 18 November 2012

Academic Editors: V. Baglio, N. Kakuta, M.-H. Li, and K. Okumura

Copyright (c) 2013 Sonali A. Borkhade et al. This is an open access article distributed under the Creative Commons Attribution License, which permits unrestricted use, distribution, and reproduction in any medium, provided the original work is properly cited.

A thermodynamic investigation of gasification coupled chemical looping combustion (CLC) of carbon (coal) is presented in this paper. Both steam and $\mathrm{CO}_{2}$ are used for gasification within the temperature range of $500-1200^{\circ} \mathrm{C}$. Chemical equilibrium model was considered for the gasifier and CLC fuel reactor. The trends in product compositions and energy requirements of the gasifier, fuel reactor, and air reactor were determined. Coal (carbon) gasification using $1.5 \mathrm{~mol} \mathrm{H}_{2} \mathrm{O}$ and $1.5 \mathrm{~mol} \mathrm{CO}$ per mole carbon at 1 bar pressure and $650^{\circ} \mathrm{C}$ delivered maximum energy $(-390.157 \mathrm{~kJ})$ from the process. Such detailed thermodynamic studies can be useful to design chemical looping combustion processes using different fuels.

\section{Introduction}

Coal is the most abundantly available cheap fossil fuel worldwide and its reserves are estimated to outlast oil and natural gas reserves [1]. Coal is mainly used for energy generation: in coal fired power plants to produce electricity [2], hydrogen [3-5], and syngas production for FT synthesis or fuel cells $[6,7]$. Combustion of coal or coal derived syngas in air results in generation of product gas mixture containing $\mathrm{CO}_{2}, \mathrm{~N}_{2}$, and $\mathrm{NO}_{x}$ [8]. The separation of $\mathrm{CO}_{2}$ from such gaseous streams is extremely difficult and expensive. Hence these product gases are directly vented to the atmosphere without $\mathrm{CO}_{2}$ separation. This environmental pollution is a major drawback of energy generation from coal. $\mathrm{CO}_{2}$ emissions from such processes are mainly responsible for global warming and climate change phenomenon [9]. The $2010 \mathrm{CO}_{2}$ emissions have increased to $389.0 \mathrm{ppm}$ and burning of fossil fuels is one of the main causes as reported by the World Meteorological Organization [10]. Such tragic scenarios were foreseen and therefore research in clean energy generation using coal had already started globally. Chemical looping combustion (CLC) technology is a result of such research efforts. CLC uses a solid oxygen carrier (OC) to oxidize the carbon and hydrogen present in the fuel to $\mathrm{CO}_{2}$ and $\mathrm{H}_{2} \mathrm{O}$, respectively, in an endothermic fuel reactor. Oxides such as $\mathrm{NiO}, \mathrm{CuO}$, and $\mathrm{Fe}_{2} \mathrm{O}_{3}$ and sulphates such as $\mathrm{CaSO}_{4}$ have been widely used as oxygen carriers in chemical looping processes. The reduced OC is regenerated by air oxidation in an exothermic air reactor $[11,12]$. Both the reactors are interconnected and operate simultaneously. The energy released in the CLC system is of similar magnitude as direct combustion, but with a crucial advantage of having $\mathrm{CO}_{2}$ and nitrogen streams completely separated [13, 14]. The pure $\mathrm{CO}_{2}$ steam can be captured/sequestered easily thereby reducing $\mathrm{CO}_{2}$ emissions to the atmosphere [15]. Coal mainly contains carbon which is a highly stable solid species and hence it requires high temperature and high energy input for chemical reactions. Further, the coal-OC system is a solid-solid complicated reaction system that has its intrinsic problems like slow reaction kinetics, low reactivity and conversions, need of gaseous medium, and so forth [16]. These problems in coal CLC system prompted researchers to search for better options. A popular option is coal gasification to syngas $\left(\mathrm{CO}+\mathrm{H}_{2}\right)$ and CLC of the generated syngas. Some research studies have been published with this theme [1721]. Coal gasification can be done using steam or $\mathrm{CO}_{2}$ or both [22-26]. Coal gasification using steam (SG) is already a developed technology [27]. The generated syngas is more 


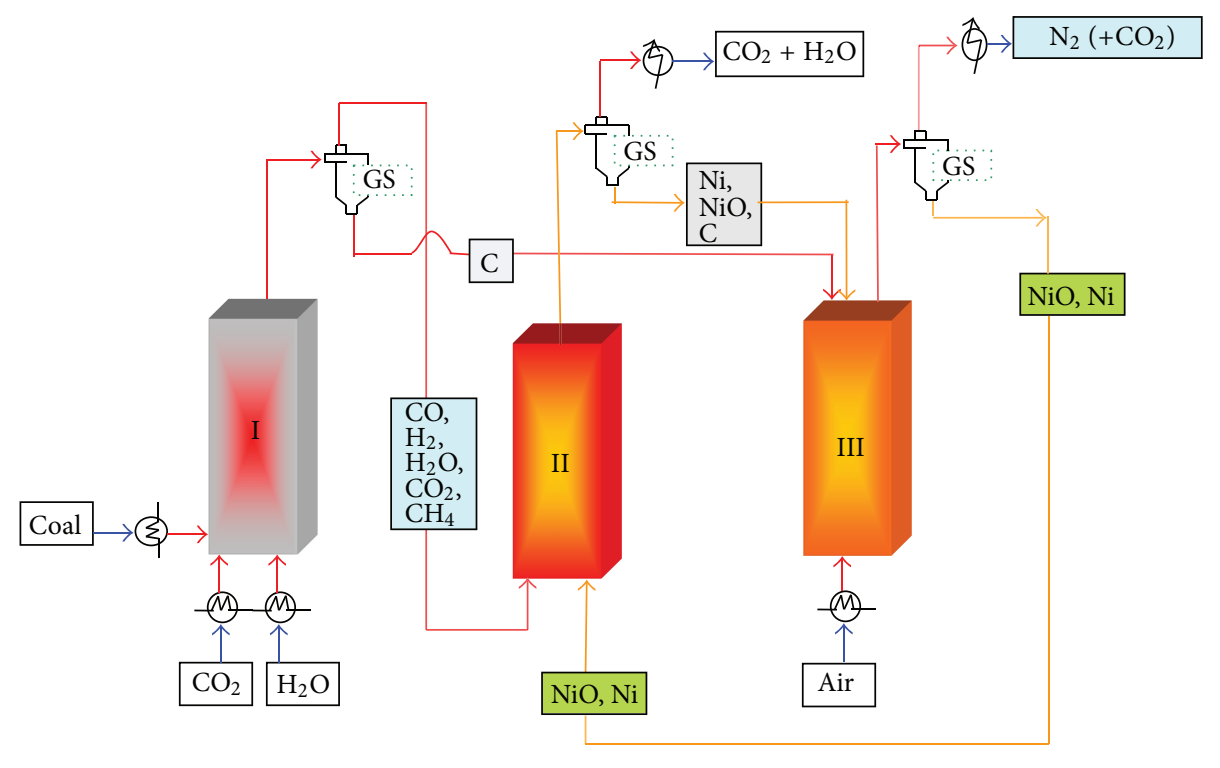

I: Gasification reactor,
II: Fuel reactor,
III: Air reactor,
GS: Gas solid separator.

FIgURE 1: Process diagram for gasification coupled chemical looping combustion of coal.

reactive gaseous species than solid coal. This syngas has high reactivity with $\mathrm{OC}$ which can help commercialization of this CLC pathway. CLC of syngas has been successfully studied by researchers with many OCs $[28,29]$. $\mathrm{NiO}$ is a very popular OC in chemical looping processes and it is used in this study. Coal gasification using $\mathrm{CO}_{2}$ (dry gasification: DG) results in $\mathrm{CO}$ rich gas, while $\mathrm{SG}$ provides syngas $\left(\mathrm{H}_{2}+\mathrm{CO}\right)$. $\mathrm{CO}_{2}$ is a relatively inert gas, not available in pure form freely, and its reaction with coal is relatively slower enabling complete conversion only at high temperatures. On the other hand, water is cheaply available, but the conversion of water to steam requires huge energy due to high latent heat of water. Hence a right combination of $\mathrm{CO}_{2}$ and steam might be useful for coal gasification to produce syngas for its further use in CLC. Coal gasification using steam $/ \mathrm{CO}_{2}$ without air is a highly endothermic process. A comprehensive theoretical research study is needed to understand the optimum conditions for the process development involving combined gasification coupled CLC of coal. Such a detailed study has not yet been published in literature. Thermodynamic studies are key starting points for chemical process design [30, 31]. Kinetics of coal gasification rely on the inorganic metal contents of coal, but thermodynamic studies that determine the maximum possible conversions under particular conditions of temperature, pressure, and feed components are not affected by these components/catalysts. Thermodynamic studies based on chemical equilibrium have been done for coal gasification systems [32-36] and also for CLC of coal [37-39]. The systematic thermodynamic study of gasification coupled CLC is presented in this paper to understand the product distribution trends at different (gasifying agent) feed, temperature, and pressure conditions to identify the best quantity of gasification agents leading to process temperatures and pressures for maximizing desired products and minimize the undesired products at maximum extractable energy from the overall process. Such a theoretical study is vital to understand the overall process aspects and reduce the time and efforts on experimentation studies which can further help fast track commercialization.

1.1. Process Description. Figure 1 shows the conceptual process design for gasification coupled CLC of coal. The process scheme consists of a gasifier, CLC fuel reactor, and CLC air reactor. Initially, preheated coal, $\mathrm{CO}_{2}$, and $\mathrm{H}_{2} \mathrm{O}$ were fed to the gasification reactor in calculated quantities to produce syngas including minor amounts of $\mathrm{CH}_{4}, \mathrm{CO}_{2}$, and $\mathrm{H}_{2} \mathrm{O}$. The gasification products were assumed to be in thermodynamic equilibrium at the exit of the gasifier. Complete conversion of coal and maximum syngas production are targeted in the gasifier. The products obtained from the gasifier at high temperature are directly fed to the fuel reactor with calculated quantity of heated $\mathrm{OC}(\mathrm{NiO})$ recirculating from the air reactor. It is assumed that the $\mathrm{NiO}$ oxidizes $\mathrm{CO}, \mathrm{H}_{2}$, and $\mathrm{CH}_{4}$ to $\mathrm{CO}_{2}$ and $\mathrm{H}_{2} \mathrm{O}$ in the CLC fuel reactor. The moles of $\mathrm{OC}(\mathrm{NiO})$ for fuel reactor are varied depending on the input moles of $\mathrm{CO}, \mathrm{H}_{2}$, and $\mathrm{CH}_{4}$ from the gasifier. Complete conversion of syngas and $\mathrm{CH}_{4}$ to $\mathrm{CO}_{2}$ and $\mathrm{H}_{2} \mathrm{O}$ is desired; however the conversion is limited by thermodynamic equilibrium. Coke 
TABLE 1: Gasification conditions.

\begin{tabular}{|c|c|c|c|c|}
\hline Feed Conditions & Input moles of carbon & Input moles of $\mathrm{CO}_{2}$ & Input moles of $\mathrm{H}_{2} \mathrm{O}$ & $\begin{array}{l}\text { Gasifying agent to carbon ratio } \\
(\mathrm{GaCR})\left(\left(\mathrm{H}_{2} \mathrm{O}+\mathrm{CO}_{2}\right) / \mathrm{C}\right)\end{array}$ \\
\hline A1 & 1 & 0 & 1 & 1 \\
\hline A2 & 1 & 0.25 & 0.75 & 1 \\
\hline A3 & 1 & 0.5 & 0.5 & 1 \\
\hline $\mathrm{A} 4$ & 1 & 0.75 & 0.25 & 1 \\
\hline A5 & 1 & 1 & 0 & 1 \\
\hline B1 & 1 & 0 & 2 & 2 \\
\hline B2 & 1 & 0.5 & 1.5 & 2 \\
\hline B3 & 1 & 1 & 1 & 2 \\
\hline B4 & 1 & 1.5 & 0.5 & 2 \\
\hline B5 & 1 & 2 & 0 & 2 \\
\hline $\mathrm{C} 1$ & 1 & 0 & 3 & 3 \\
\hline $\mathrm{C} 2$ & 1 & 1 & 2 & 3 \\
\hline C3 & 1 & 1.5 & 1.5 & 3 \\
\hline $\mathrm{C} 4$ & 1 & 2 & 1 & 3 \\
\hline C5 & 1 & 3 & 0 & 3 \\
\hline
\end{tabular}

formation can also take place in the CLC fuel reactor. The OC $(\mathrm{NiO})$ gets reduced (to $\mathrm{Ni}$ ) in the CLC fuel reactor. The products of the CLC fuel reactor pass through a gassolid separator and the gaseous products mainly containing $\mathrm{CO}_{2}$ and $\mathrm{H}_{2} \mathrm{O}$ may be partly recycled to the gasifier (if pure) and the rest can be cooled for $\mathrm{CO}_{2}$ separation and sequestration with heat recovery. The solid products of the fuel reactor mainly containing OC (and coke) are transferred to the air reactor, in which preheated air is added for complete oxidation of coke to $\mathrm{CO}_{2}$ and regeneration of reduced $\mathrm{OC}$. It is assumed that these oxidation reactions go to complete conversion. The regenerated $\mathrm{NiO}$ is separated from the air reactor product stream by a gas-solid separator and is recycled back to the fuel reactor. The air reactor is the major source of heat in the entire process. It is assumed that the three reactors (gasifier, fuel, and air reactor) operate at same temperature and pressure. This study assumes energy for chemical reactions (including heating/cooling) only and other energies such as OC transport energy, coal feeder energy, gas-solid separator energy, and heat losses are not considered in this basic theoretical study.

1.2. Process Methodology. HSC Chemistry software version 5.11 is used to generate the thermodynamic equilibrium data for gasifier and CLC fuel reactor in this process design study $[40,41]$. Thermodynamic equilibrium calculations in the Gibbs routine of HSC Chemistry are done using the Gibbs free energy minimization method. The Gibbs program finds the best combination of most stable species where the Gibbs free energy of the system achieves its minimum at a fixed mass balance (a constraint minimization problem), constant pressure, and temperature. Hence chemical reaction equations are not required in the input. The carbon content (in weight) in coal is variable, generally varying from 35-85\% depending on its origin (American, Australian, Chinese, etc.). Coal also contains minor amounts of hydrogen $(\sim 5 \%)$, oxygen $(\sim 7 \%)$, sulfur $(<1 \%)$, ash, and so forth. Generally carbon, hydrogen, and sulphur can contribute to energy generation, but the quantity of hydrogen and sulphur is not much compared to the carbon content of coal. Hence only pure carbon (solid) is used to model coal in this study. This assumption is made to compare the results of this novel process study with standard heat of combustion of carbon which is a unique value compared to the coal combustion values which vary a lot. Species such as $\mathrm{C}(\mathrm{s}), \mathrm{CO}_{2}(\mathrm{~g})$, $\mathrm{H}_{2}$ (g), $\mathrm{CO}(\mathrm{g}), \mathrm{H}_{2} \mathrm{O}$ (g), $\mathrm{CH}_{4}$ (g), $\mathrm{H}_{2} \mathrm{O}$ (l), $\mathrm{O}_{2}$ (g), $\mathrm{NiO}$ (s) and $\mathrm{Ni}(\mathrm{s})$, which are usually found in the gasification and CLC reaction systems are considered in this study. The input species to the gasifier were $\mathrm{C}(\mathrm{s}), \mathrm{H}_{2} \mathrm{O}(\mathrm{g})$, and $\mathrm{CO}_{2}$ (g) reacting to give the products. The material balances are done by Equilibrium Composition module of HSC Chemistry and these results were used to calculate reaction enthalpy by Reaction Equation module of HSC Chemistry software. The results may be slightly different using different software as all softwares use their own databank of chemical properties. The results presented are within reasonable error limit $( \pm 1 \%)$. Any other inert in feed, by-product formation is not considered in this study. The gasification reaction chemistry for coal is well established in chemical literature and hence no such details are presented in this paper. $1 \mathrm{~mol}$ carbon has been used as basis for all calculations in the temperature range of $500-1200^{\circ} \mathrm{C}$ for the entire process. Coal gasification is done using steam and $\mathrm{CO}_{2}$. The feed gasifying agent-to-carbon ratio (GaCR) ranging from 1 to 3 was selected for the study. Combined gasification of carbon (CG) using both $\mathrm{CO}_{2}$ and $\mathrm{H}_{2} \mathrm{O}$ is also considered in this study and its intermediate steps for increase in $\mathrm{CO}_{2}$ moles (with simultaneous decrease in steam moles) for constant $\mathrm{GaCR}$ ratios were also considered in the calculations. These feed conditions for $\mathrm{CO}_{2}$ and steam input per mole coal input are shown in Table 1. These inputs were used to calculate the thermodynamic equilibrium compositions in the process reactors and are discussed in detail in the next section with their respective reactor energies. The oxidation reaction in 


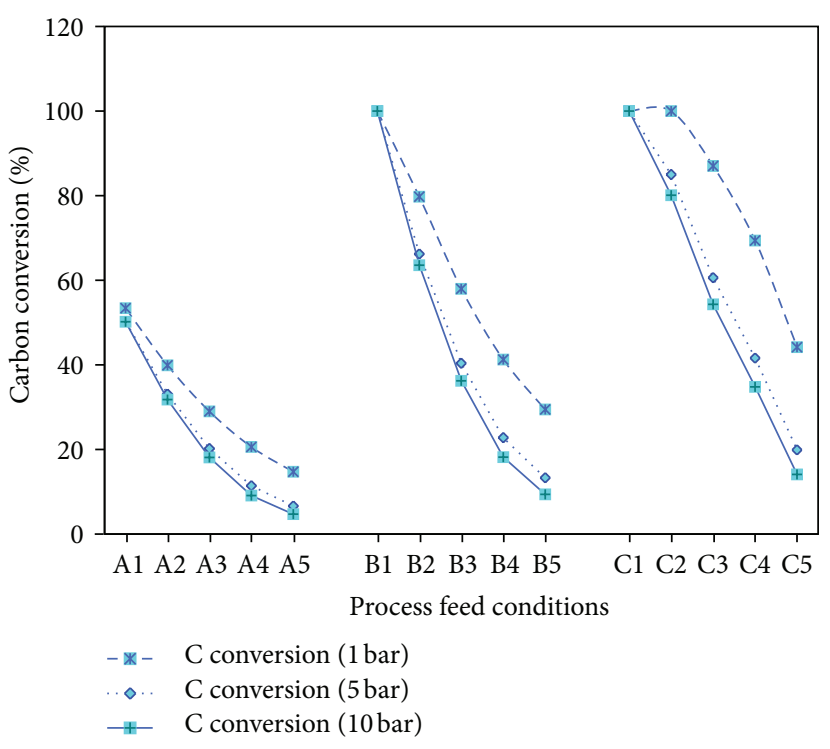

(a)

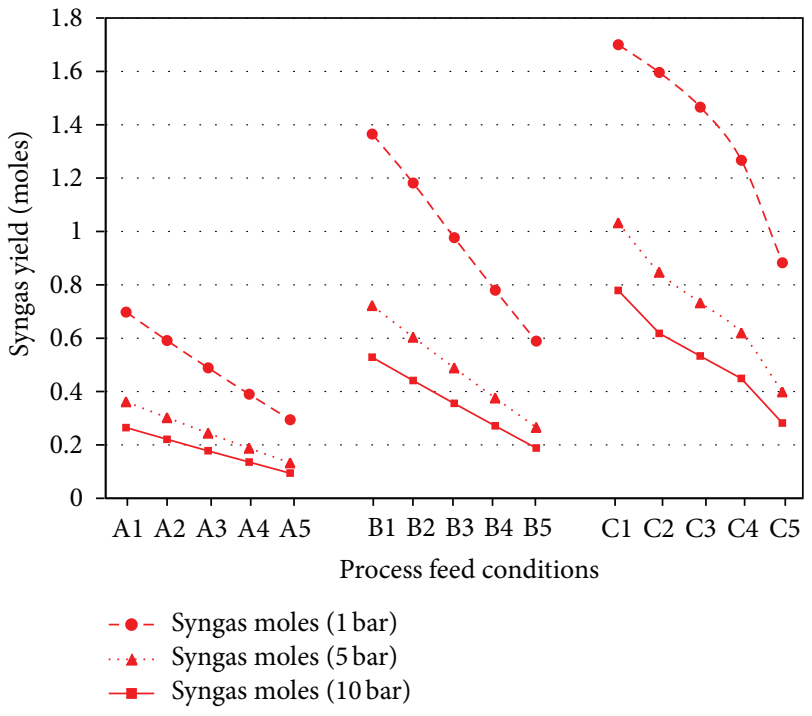

(b)

FIGURE 2: (a) Carbon conversion in gasifier at $600^{\circ} \mathrm{C}$. (b) Syngas yield in gasifier at $600^{\circ} \mathrm{C}$.

the air reactor is highly exothermic. It is assumed that the air supplied to the air reactor is in stoichiometric amount given by the reactions

$$
\begin{gathered}
\mathrm{Ni}+0.5 \mathrm{O}_{2}=\mathrm{NiO} \\
\mathrm{C}+\mathrm{O}_{2}=\mathrm{CO}_{2}
\end{gathered}
$$

The equilibrium compositions of the coal gasifier and CLC fuel reactor were used to calculate the energy involved in those reactors. For example, the equilibrium product composition for case B2 in the gasifier was $\left[0.51 \mathrm{CO}_{2}(\mathrm{~g})\right.$, $\left.0.49 \mathrm{H}_{2} \mathrm{O}(\mathrm{g}), 0.99 \mathrm{CO}(\mathrm{g}), 1.01 \mathrm{H}_{2}(\mathrm{~g})\right]$ at $800^{\circ} \mathrm{C}$. This product composition was used to formulate the following reaction:

$$
\begin{aligned}
\mathrm{C}+1.5 \mathrm{H}_{2} \mathrm{O}(\mathrm{g})+0.5 \mathrm{CO}_{2}(\mathrm{~g})= & 0.51 \mathrm{CO}_{2}(\mathrm{~g})+0.49 \mathrm{H}_{2} \mathrm{O}(\mathrm{g}) \\
& +0.99 \mathrm{CO}(\mathrm{g})+1.01 \mathrm{H}_{2}(\mathrm{~g})
\end{aligned}
$$

This reaction was fed to the Reaction Equation module of HSC Chemistry software and the reaction enthalpy of $\Delta H=135.43 \mathrm{~kJ}$ at $800^{\circ} \mathrm{C}$ was obtained. Similar strategy was followed for CLC fuel reactor material and energy balances. The calculations for the air reactor were done using reactions equations only as complete conversion (no equilibrium) was assumed. The general calculations required to determine energy requirements of heating and cooling of chemical species were done manually using standard data [42].

\section{Results and Discussions}

2.1. Effect of Pressure. Pressure is an important process parameter. The effect of pressure on gasification coupled CLC of coal was investigated for 1, 5, and 10 bars. Initially, the effect of pressure on carbon conversion and syngas yield in the gasifier was studied. It was observed that the theoretical carbon conversion reached a maximum value (approximately $100 \%)$ at higher temperatures $\left(>600^{\circ} \mathrm{C}\right)$. Hence the effect of pressure was studied at $600^{\circ} \mathrm{C}$ only. Figure 2 (a) shows the carbon conversion at $600^{\circ} \mathrm{C}$ for the 15 feed input conditions (A1-C5). It was observed that the carbon conversion generally decreased with increase in pressure for all cases. It was also observed that the carbon conversion in CG at constant pressure generally decreased with increase in feed $\mathrm{CO}_{2}$ moles at constant GaCR for all pressures. It was also seen that the carbon conversion increased as the feed steam to carbon ratio (SCR) increased from 1 to 3 for all pressures for SG cases (A1, B1) and sometimes saturated at 100\% $(B 1, C 1)$. Similar observation was also noted for DG cases (A5, B5, C5) with increase in the feed $\mathrm{CO}_{2}$ to carbon ratio (CCR) from 1 to 3 . Figure 2(b) shows the syngas yield for the different feed conditions at $600^{\circ} \mathrm{C}$. It was observed that the syngas yield decreased with increase in pressure for all cases. It was also observed that the syngas yield in CG at constant pressure decreased with increase in feed $\mathrm{CO}_{2}$ moles at constant $\mathrm{GaCR}$ for all pressures. It was also seen that the syngas yield increased as the respective feed GaCR increased from 1 to 3 for all pressures for SG cases (A1, B1, C1) and for DG cases (A5, B5, C5).

Considering the negative effect of pressure on carbon conversion and syngas yield in the gasifier, it was noted that the maximum carbon conversion with maximum syngas yield can be achieved at low pressure (1 bar). Hence 1 bar pressure was selected for further analysis of gasification coupled CLC process. The carbon conversion in the gasifier for the different feed conditions at 1 bar pressure is shown in Table 2. It was observed that the carbon conversion reached its maximum $(100 \%)$ as the gasification temperature increased from $500-1200^{\circ} \mathrm{C}$. It was generally observed that higher GaCR required relatively lower temperatures for $100 \%$ 
TABLE 2: Carbon conversion in gasifier.

\begin{tabular}{|c|c|c|c|c|c|c|c|c|c|c|c|c|c|c|c|}
\hline \multirow{2}{*}{$\begin{array}{l}\text { Temperature }\left({ }^{\circ} \mathrm{C}\right) \\
\text { Feed Conditions }\end{array}$} & 500 & 550 & 600 & 650 & 700 & 750 & 800 & 850 & 900 & 950 & 1000 & 1050 & 1100 & 1150 & 1200 \\
\hline & & \multicolumn{14}{|c|}{ Carbon conversion $\%$} \\
\hline$\overline{\mathrm{A} 1}$ & 46 & 48 & 54 & 62 & 73 & 84 & 92 & 96 & 98 & 99 & 100 & 100 & 100 & 100 & 100 \\
\hline A2 & 29 & 33 & 40 & 51 & 65 & 79 & 88 & 94 & 97 & 98 & 99 & 100 & 100 & 100 & 100 \\
\hline A3 & 16 & 21 & 29 & 41 & 57 & 73 & 85 & 93 & 96 & 98 & 99 & 99 & 100 & 100 & 100 \\
\hline A4 & 8 & 13 & 21 & 34 & 51 & 69 & 83 & 91 & 96 & 98 & 99 & 99 & 100 & 100 & 100 \\
\hline A5 & 3 & 7 & 15 & 28 & 46 & 65 & 81 & 90 & 95 & 97 & 99 & 99 & 100 & 100 & 100 \\
\hline B1 & 91 & 97 & 100 & 100 & 100 & 100 & 100 & 100 & 100 & 100 & 100 & 100 & 100 & 100 & 100 \\
\hline B2 & 57 & 66 & 80 & 100 & 100 & 100 & 100 & 100 & 100 & 100 & 100 & 100 & 100 & 100 & 100 \\
\hline B3 & 32 & 42 & 58 & 83 & 100 & 100 & 100 & 100 & 100 & 100 & 100 & 100 & 100 & 100 & 100 \\
\hline B4 & 16 & 25 & 42 & 67 & 100 & 100 & 100 & 100 & 100 & 100 & 100 & 100 & 100 & 100 & 100 \\
\hline B5 & 7 & 15 & 30 & 55 & 91 & 100 & 100 & 100 & 100 & 100 & 100 & 100 & 100 & 100 & 100 \\
\hline $\mathrm{C} 1$ & 100 & 100 & 100 & 100 & 100 & 100 & 100 & 100 & 100 & 100 & 100 & 100 & 100 & 100 & 100 \\
\hline $\mathrm{C} 2$ & 72 & 86 & 100 & 100 & 100 & 100 & 100 & 100 & 100 & 100 & 100 & 100 & 100 & 100 & 100 \\
\hline C3 & 49 & 63 & 88 & 100 & 100 & 100 & 100 & 100 & 100 & 100 & 100 & 100 & 100 & 100 & 100 \\
\hline $\mathrm{C} 4$ & 31 & 45 & 70 & 100 & 100 & 100 & 100 & 100 & 100 & 100 & 100 & 100 & 100 & 100 & 100 \\
\hline $\mathrm{C} 5$ & 10 & 22 & 45 & 83 & 100 & 100 & 100 & 100 & 100 & 100 & 100 & 100 & 100 & 100 & 100 \\
\hline
\end{tabular}

carbon conversion and the $100 \%$ carbon conversion in SG occurred at relatively lower temperatures than analogous DG cases. The minimum temperatures for $100 \%$ carbon conversion (HCCT: Hundred percent Carbon Conversion Temperature) were important and sufficient for this process design. Hence these HCCTs (Bold in Table 2) were selected for further process analysis for the respective feed conditions. Thus the pressure and temperature for the process reactors were fixed for further process design. The product/energy analysis of the individual reactors depended solely on the feed composition conditions and is discussed in the next sections.

2.2. Products of the Gasifier. The product composition of the gasifier obtained for the various (A1 to C5) feed conditions at 1 bar pressure and respective HCCTs was analyzed and plotted in Figure 3.

2.2.1. Syngas. Syngas is the most desired product of the coal gasifier. As seen in Figure 3, the syngas yield in CG generally increased with increase in feed $\mathrm{CO}_{2}$ moles at constant $\mathrm{GaCR}$ and reached a maximum for almost all cases. The maximum syngas yield was found to be $2.00 \mathrm{~mol}$ (cases B5 and C5), while the minimum yield was observed to be $0.95 \mathrm{~mol}$ (case $\mathrm{C} 1)$. It was observed that the syngas yield for the SG cases (A1, B1, C1) decreased with increase in SCR; but the syngas yield was almost constant (approximately $2.00 \mathrm{~mol}$ ) for DG cases (A5, B5, C5), while the syngas yield slightly decreased for equimolar input moles of $\mathrm{H}_{2} \mathrm{O}$ and $\mathrm{CO}_{2}$ with increase in GaCR from 1 to 3 (cases A3, B3, C3). Similarly, the trends of the individual $\mathrm{H}_{2}$ and $\mathrm{CO}$ gases were also analysed and presented in Figure 3.

2.2.2. Methane. Methane is not a desirable product of gasifier, but is inevitably formed in the gasification process (where steam is in the input). As depicted from Figure 3, the methane yield in CG generally decreased with increase

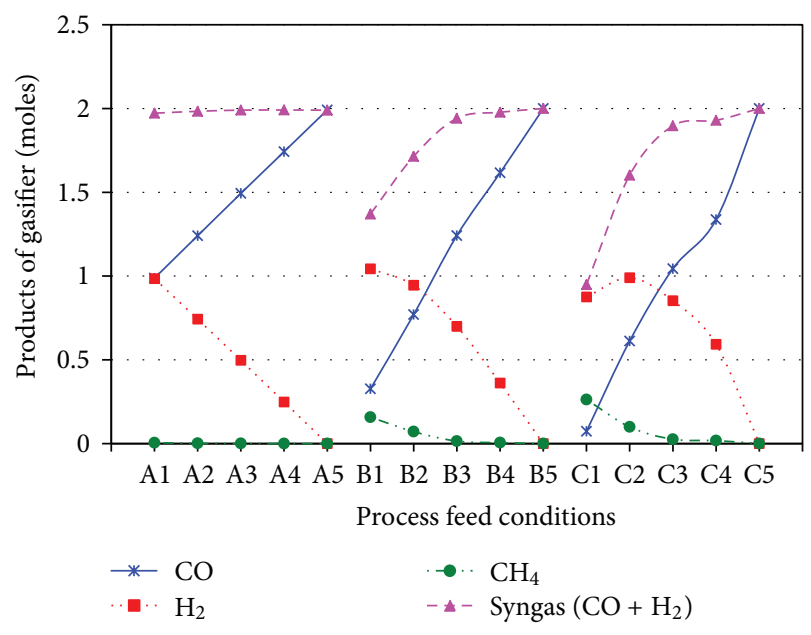

FIGURE 3: Products of gasifier at different feed conditions.

in feed $\mathrm{CO}_{2}$ moles at constant GaCR (except for A1-A5 conditions where it was almost zero). The methane yield slightly increased for equimolar input moles of $\mathrm{H}_{2} \mathrm{O}$ and $\mathrm{CO}_{2}$ with increase in GaCR from 1 to 3 (cases A3, B3, and C3). As a general observation, the methane yield was insignificant in the gasification product gas at the conditions ( 1 bar process pressure) chosen in the process design study.

2.3. Energy Analysis of Gasifier. Coal Gasifier has two main continuous energy demands for consideration: preheating energy (energy to preheat the gasification reactor raw materials: coal, water, and $\mathrm{CO}_{2}$ to the gasifier temperature) and gasifier enthalpy (energy required for endothermic gasification reactions). The trends in the gasification reactor enthalpy, gasifier feed preheating requirements, and net energy of the gasifier were studied at 1 bar pressure and respective HCCTs for the different feed conditions (A1 to C5) based on the 


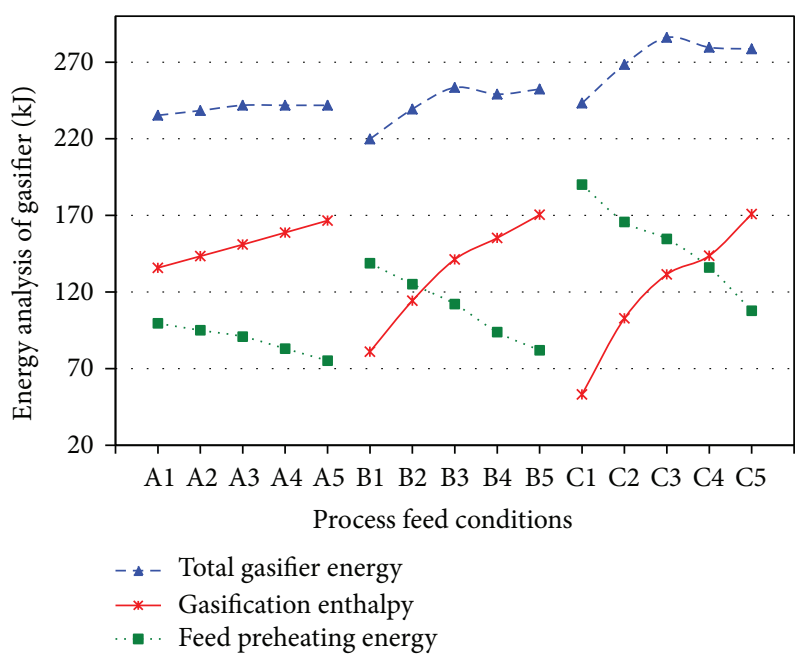

FIgURE 4: Energies in gasification process.

equilibrium compositions obtained in the earlier section and are shown in Figure 4.

2.3.1. Gasification Enthalpy. Carbon gasification in absence of air is an endothermic process. It was observed from Figure 4 that the gasification reaction endothermicity generally increased with increase in feed $\mathrm{CO}_{2}$ moles at constant $\mathrm{GaCR}$ for all $\mathrm{CG}$ cases. The maximum gasifier enthalpy was found to be $170.86 \mathrm{~kJ}$ (case C5), while the minimum reaction enthalpy was observed to be $52.36 \mathrm{~kJ}$ (case $\mathrm{C} 1$ ). The gasification enthalpy for the SG cases (A1, B1, C1) decreased with increase in SCR, while the reaction enthalpy for DG cases (A5, B5, C5) slightly increased with increase in CCR. It was also observed that the gasification enthalpy decreased for equimolar input of $\mathrm{H}_{2} \mathrm{O}$ and $\mathrm{CO}_{2}$ with increase in $\mathrm{GaCR}$ from 1 to 3 (cases A3, B3, and C3).

2.3.2. Preheating Energy. As seen in Figure 4, the preheating energy generally decreased with increase in feed $\mathrm{CO}_{2}$ moles at constant $\mathrm{GaCR}$ for all CG cases. The maximum preheating energy was found to be $190.08 \mathrm{~kJ}$ for case C1 (highest steam input), while the minimum preheating energy was observed to be $75.22 \mathrm{~kJ}$ for case A5. The preheating energy for the SG (cases A1, B1, and C1) increased with increase in SCR and similarly the preheating energy for DG (cases A5, B5, and C5) also increased with increase in CCR. This was due to the huge difference of HCCT of feed conditions. The preheating energy requirement increased for equimolar input of $\mathrm{H}_{2} \mathrm{O}$ and $\mathrm{CO}_{2}$ with increase in GaCR from 1 to 3 (cases A3, B3, and C3), that is, it increased from 90.90 to $154.65 \mathrm{~kJ}$ (from A3 to C3).

2.3.3. Total Gasification Energy. The total energy required for gasification is the sum of gasification enthalpy and preheating energy. It was seen that SG requires higher preheating energy, while DG requires higher gasification enthalpy. As seen in Figure 4, the total gasification energy for CG generally increased up to $\mathrm{A} 3, \mathrm{~B} 3$, and $\mathrm{C} 3$ with increase in feed $\mathrm{CO}_{2}$ moles (with simultaneous decrease in feed $\mathrm{H}_{2} \mathrm{O}$ moles) at constant GaCR and afterwards followed their individual trends. The maximum total energy requirement for gasification was found to be $286.50 \mathrm{~kJ}$ (case C3), while the minimum total gasification energy was observed to be $219.99 \mathrm{~kJ}$ (case $\mathrm{B} 1)$. The total energy for the SG (A1, B1, C1) first decreased (due to huge difference of HCCTs) and then increased with increase in SCR, while the total energy for DG cases (A5, B5, C5) only increased with increase in CCR. The total energy for gasification increased for equimolar input of $\mathrm{H}_{2} \mathrm{O}$ and $\mathrm{CO}_{2}$ with increase in GaCR from 1 to 3 (cases A3, B3, and C3).

2.4. OC Requirement of CLC Fuel Reactor. The gasifier product gas contains $\mathrm{H}_{2}, \mathrm{CO}$, and $\mathrm{CH}_{4}$ which are reactive species for CLC fuel reactor. The OC requirement in the CLC fuel reactor depends on the input quantities of these gases which in turn depend on the feed input variations to the gasifier. The product distribution trend of the gasifier product gases has already been discussed in the earlier sections. The stoichiometric requirement of OC (S) for different feed inputs was calculated according to (4), (5), and (6) reactions:

$$
\begin{gathered}
\mathrm{H}_{2}+\mathrm{NiO}=\mathrm{H}_{2} \mathrm{O}+\mathrm{Ni} \\
\mathrm{CO}+\mathrm{NiO}=\mathrm{CO}_{2}+\mathrm{Ni} \\
\mathrm{CH}_{4}+4 \mathrm{NiO}=\mathrm{CO}_{2}+2 \mathrm{H}_{2} \mathrm{O}+4 \mathrm{Ni}
\end{gathered}
$$

Although these main reactions occur, some side reactions also take place and hence the conversions in the fuel reactor are limited by thermodynamic equilibrium constraints. It was therefore necessary to study the equilibrium product composition of the CLC fuel reactor using stoichiometric amount of $\mathrm{OC}$ (Case $\mathrm{S}$ ) at 1 bar pressure and respective HCCTs. However the OC is generally used in excess of the stoichiometric requirement in CLC processes to enhance the syngas and $\mathrm{CH}_{4}$ conversion in the fuel reactor. Hence two more cases (1.5S and $2 \mathrm{~S}$ ) using higher amounts (1.5 times and 2.0 times the stoichiometric requirement) of $\mathrm{OC}$ were also investigated. Figure 5 shows the syngas and $\mathrm{CH}_{4}$ compositions in product gases of the CLC fuel reactor for different inputs of $\mathrm{OC}$ at various process feed inputs at $1 \mathrm{bar}$ pressure and respective HCCTs. It was observed that the $\mathrm{H}_{2}$, $\mathrm{CO}$, and $\mathrm{CH}_{4}$ emissions from the fuel reactor decreased with increase in the amount of OC. It was also observed that the $\left(\mathrm{CH}_{4}+\mathrm{CO}+\mathrm{H}_{2}\right)$ moles generally increased with increase in feed $\mathrm{CO}_{2}$ moles at constant $\mathrm{GaCR}$ except for some cases like $\mathrm{B} 4$ and $\mathrm{C} 4$. The maximum amount of $\left(\mathrm{CH}_{4}+\mathrm{CO}+\right.$ $\mathrm{H}_{2}$ ) exit moles were found to be $0.226 \mathrm{~mol}$ (A5), while the minimum quantity of $\left(\mathrm{CH}_{4}+\mathrm{CO}+\mathrm{H}_{2}\right)$ exit moles were observed to be $0.127 \mathrm{~mol}$ (B1). Higher reactor temperatures (A1-A5) produced relatively higher $\left(\mathrm{CH}_{4}+\mathrm{CO}+\mathrm{H}_{2}\right)$ moles for stoichiometric $\mathrm{OC}$ usage. The decrease in $\left(\mathrm{CH}_{4}+\mathrm{CO}+\right.$ $\mathrm{H}_{2}$ ) emissions from the CLC fuel reactor was very significant between $\mathrm{S}$ and $1.5 \mathrm{~S}$ conditions, while these emissions were of almost similar magnitude for the use of $1.5 \mathrm{~S}$ and $2 \mathrm{~S} \mathrm{OC}$ inputs. The complete conversion of syngas and methane to $\mathrm{CO}_{2}$ and $\mathrm{H}_{2} \mathrm{O}$ is highly beneficial in the CLC fuel reactor. Hence the amount of $\mathrm{OC}$ to be used in the process was fixed to $1.5 \mathrm{~S}$ (1.5 times the stoichiometric OC requirement) for further process calculations. 


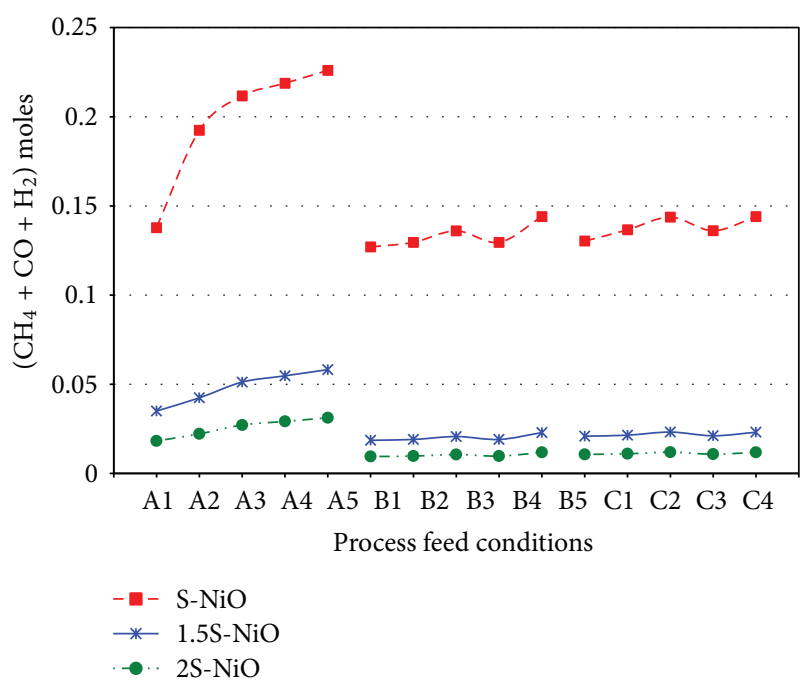

Figure 5: $\left(\mathrm{CH}_{4}+\mathrm{CO}+\mathrm{H}_{2}\right)$ moles emitted from the fuel reactor.

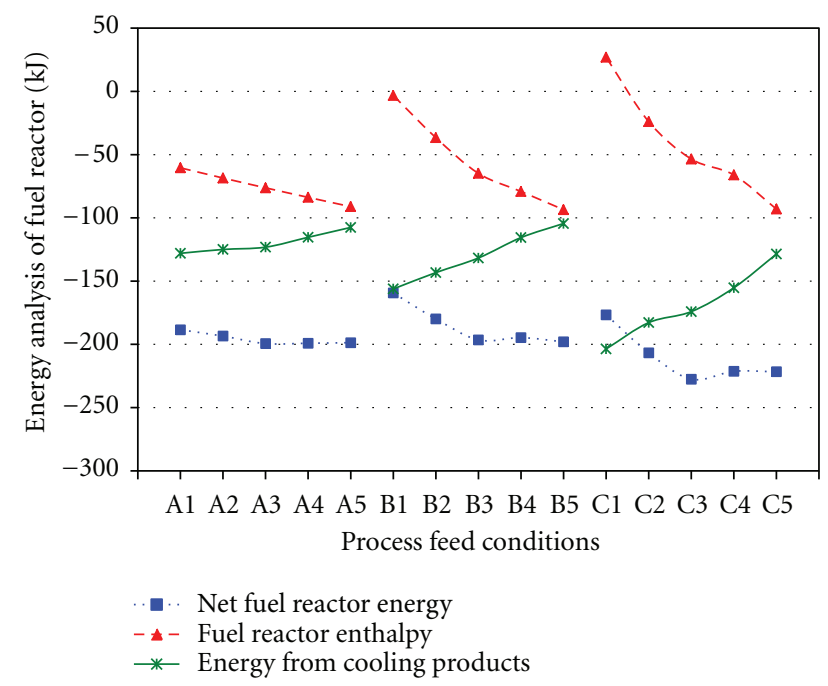

Figure 6: Energies of the CLC fuel reactor.

2.5. Energy Analysis of Fuel Reactor. At a steady state process operation, the fuel reactor receives hot OC from air reactor and hot syngas rich stream from the gasifier. Due to equal reactor temperature assumption, it does not have any feed preheating requirements. The only energy calculations are the fuel reactor enthalpy and energy recoverable from product gases. These fuel reactor energies and the resulting net fuel reactor energies at $1 \mathrm{bar}$ pressure and respective HCCTs were calculated for the different feed conditions (A1 to C5) using the equilibrium compositions obtained in the earlier sections and are plotted in Figure 6.

2.5.1. Fuel Reactor Enthalpy. The fuel reactor enthalpy depends mainly on the syngas and methane content of the gasifier product gas. As seen in Figure 6, the exothermicity of the fuel reactor generally increased with increase in feed $\mathrm{CO}_{2}$ moles at constant $\mathrm{GaCR}$ for all cases. The maximum exothermicity was found to be $-93.195 \mathrm{~kJ}$ (case B5), while the minimum reactor enthalpy was observed to be $27.44 \mathrm{~kJ}$ (case C1). The exothermicity for the SG cases (A1, B1, C1) decreased with increase in SCR, while in DG cases (A5, B5, C5), the fuel reactor exothermicity was almost constant as the CCR was increased from 1 to 3 . It was seen that, the fuel reactor exothermicity decreased for equimolar input of $\mathrm{H}_{2} \mathrm{O}$ and $\mathrm{CO}_{2}$ with increase in $\mathrm{GaCR}$ from 1 to 3 (cases $\mathrm{A} 3, \mathrm{~B} 3$, and $\mathrm{C} 3$ ).

2.5.2. Extractable Energy by Cooling Fuel Reactor Products. The main gaseous products of the fuel reactor are $\mathrm{CO}_{2}$ and $\mathrm{H}_{2} \mathrm{O}$ at high fuel reactor temperature (except cases A5, B5, and $\mathrm{C} 5$ where only $\mathrm{CO}_{2}$ is emitted by the fuel reactor which can be directly recycled to the gasifier after purging and makeup). For other cases, it was found that minor amount of $\mathrm{H}_{2}, \mathrm{CO}$, and $\mathrm{CH}_{4}$ are also present in the gaseous streams and the $\mathrm{CO}_{2} / \mathrm{H}_{2} \mathrm{O}$ ratio of the fuel reactor product gas was not near to the gasifier $\mathrm{CO}_{2} / \mathrm{H}_{2} \mathrm{O}$ ratio requirement. All the 15 streams were considered for heat recovery by cooling to $25^{\circ} \mathrm{C}$. It was observed that higher $\left(\mathrm{H}_{2}+\mathrm{CH}_{4}\right)$ gasifier stream produced higher steam in fuel reactor which on cooling gave higher extractable energy. As depicted in Figure 6, the extractable energy by cooling products generally decreased with increase in feed $\mathrm{CO}_{2}$ moles at constant $\mathrm{GaCR}$ for all CG cases. The maximum extractable energy by cooling the products was found to be $-203.83 \mathrm{~kJ}$ (case C1, max. steam input to process), while the minimum extractable energy was seen for case B5 (-104.55 kJ-zero steam input). It was also observed that the extractable energy for the SG cases (A1, B1, C1) increased with increase in SCR (higher steam input gave higher energy on cooling), while in DG cases, that is, A5, B5 and C5, the extractable energy from cooling product gases first slightly decreased from $-108.027 \mathrm{~kJ}$ to $-104.55 \mathrm{~kJ}$ (A5 and B5) and then increased to $-128.708 \mathrm{~kJ}$ (C5) with gradual increase in CCR. It was also observed that the extractable energy increased for cases of equimolar input of $\mathrm{H}_{2} \mathrm{O}$ and $\mathrm{CO}_{2}$ with increase in $\mathrm{GaCR}$ from 1 to 3 (cases $\mathrm{A} 3, \mathrm{~B} 3$, and $\mathrm{C} 3$ ).

2.5.3. Net Energy of Fuel Reactor. It was observed from Figure 6 that the net energy of the fuel reactor was in the exothermic region for all cases (due to syngas feed). The net energy exothermicity of the fuel reactor in CG cases increased with increase in $\mathrm{CO}_{2}$ moles till $\mathrm{A} 3, \mathrm{~B} 3$, and $\mathrm{C} 3$ for respective $\mathrm{GaCR}$ and then followed individual trends as shown in the figure. It was also observed that the range of net energy increased with increase in GaCR from 1 to 3. The maximum exothermicity was found to be $-228.06 \mathrm{~kJ}$ (case C3), while the minimum exothermicity was observed to be $-158.34 \mathrm{~kJ}$ (case B1).

2.6. Material Balance for Air Reactor. The air reactor continuously receives hot depleted OC and carbon from the fuel reactor; unconverted carbon from the gasifier and preheated air to oxidize them to $\mathrm{NiO}$ and $\mathrm{CO}_{2}$ completely. In this study, the unconverted carbon from the gasifier and carbon formed in the fuel reactor were negligible (due to choice of process conditions). The air supply was in exact stoichiometric 


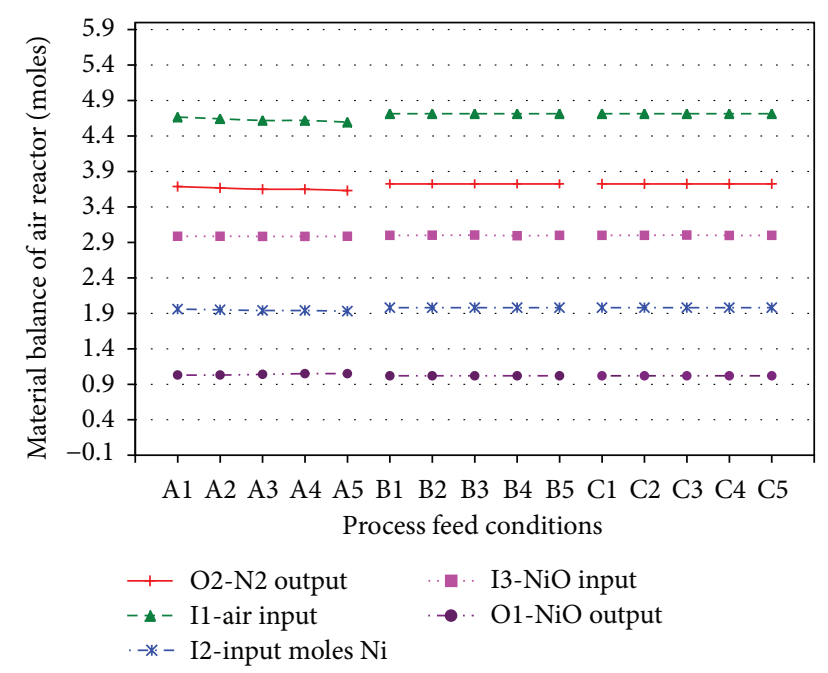

FIGURE 7: Input and output species of air reactor.

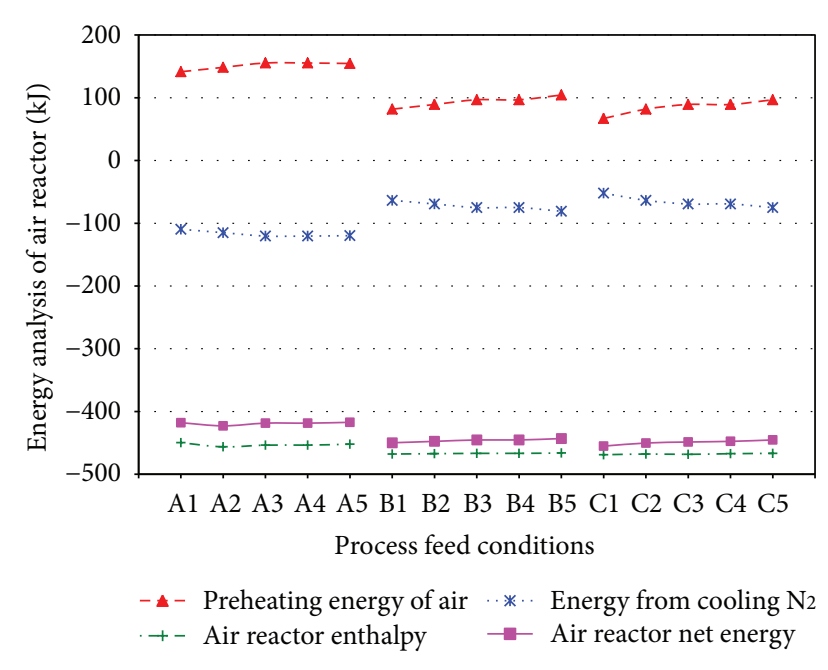

FIGURE 8: Energies of CLC air reactor.

requirement for the $\mathrm{Ni}$ oxidation for its complete conversion to $\mathrm{NiO}$ in this study. Figure 7 shows the inputs and outputs of the air reactor at different feed conditions at 1 bar pressure and HCCTs. The input streams to the air reactor are I1-air, $\mathrm{I} 2-\mathrm{Ni}$, and $\mathrm{I} 3-\mathrm{NiO}$, while the output streams of the air reactor are $\mathrm{O} 1-\mathrm{NiO}$ and $\mathrm{O} 2$-nitrogen. It was observed that there were only slight variations in each stream for the 15 feed conditions considered in this study and hence detailed analysis was not done for this part of study.

2.7. Energy Analysis of Air Reactor. The material balances of the air reactor (discussed in the earlier section) were used to calculate the energy of the air reactor streams. Figure 8 shows the trends in air preheating energy requirement, air reactor enthalpy, energy extracted by cooling of nitrogen, and resulting net energy of air reactor at 1 bar pressure and HCCT for the different feed conditions (A1 to C5). It was seen that the air requirements for the individual 15 cases were almost similar and hence the HCCTs dominated the energy calculations.

2.7.1. Preheating Energy Requirement. The air reactor receives preheated air for OC regeneration. As seen in Figure 8 , the preheating energy generally increased with increase in feed $\mathrm{CO}_{2}$ moles at constant GaCR for all CG cases. It was also observed that the air preheating energy requirement generally decreased with increase in combined GaCR due to relatively lower HCCTs. The preheating energy of air for the SG cases (A1, B1, C1) decreased with increase in SCR and similar observation was noted for DG cases (A5, B5, C5). The preheating energy of air decreased for equimolar input of $\mathrm{H}_{2} \mathrm{O}$ and $\mathrm{CO}_{2}$ with increase in GaCR from 1 to 3 (cases A3, B3, and $\mathrm{C} 3$ ). The maximum preheating energy of air was found to be $155.41 \mathrm{~kJ}$ (A3) at $1100^{\circ} \mathrm{C}$ and minimum preheating energy requirement of air was found to be $67.016 \mathrm{~kJ}(\mathrm{C} 1)$ at $500^{\circ} \mathrm{C}$.

2.7.2. Air Reactor Enthalpy. Energy generation in the air reactor is the most important aspect for the process as the air reactor supplies energy for the entire process. It was observed from Figure 8 that the exothermicity of the air reactor slightly varied for all subcases of constant GaCR and it slightly increased with increase in GaCR from 1 to 2 but was almost constant for GaCR 2 and 3 due to nearby individual case HCCTs. The exothermicity of air reactor increased for equimolar input of $\mathrm{H}_{2} \mathrm{O}$ and $\mathrm{CO}_{2}$ with increase in $\mathrm{GaCR}$ from 1 to 3 (cases A3, B3, and C3), that is, it increased from $-453.56 \mathrm{~kJ}$ (A3) to $-466.69 \mathrm{~kJ}$ (B3) till $-468.25 \mathrm{~kJ}$ (C3). The maximum exothermicity of the air reactor was found to be $-468.88 \mathrm{~kJ}(\mathrm{C} 1)$ at $500^{\circ} \mathrm{C}$, while the minimum exothermicity was observed for case A1 $(-449.72 \mathrm{~kJ})$ at $1100^{\circ} \mathrm{C}$.

2.7.3. Energy Extracted by Cooling Nitrogen. Oxygen from air is used up in the air reactor for regeneration of depleted OC and carbon oxidation. The left-over hot nitrogen gas evolving out of the air reactor can be cooled to $25^{\circ} \mathrm{C}$ and energy can be extracted for use in the process. It was seen in Figure 8 that this extracted energy generally increased with increase in feed $\mathrm{CO}_{2}$ moles at constant GaCR except for case A3, A4, and $\mathrm{A} 5$ where it remained almost constant. It was also seen that the exothermicity for SG cases (A1, B1, C1) and also for DG cases (A5, B5, C5) decreased with increase in respective GaCR due to relatively lower HCCTs. It was also observed that the exothermicity decreased for equimolar input of $\mathrm{H}_{2} \mathrm{O}$ and $\mathrm{CO}_{2}$ with increase in $\mathrm{GaCR}$ from 1 to 3 (cases A3, B3, and C3). The maximum extractable energy by cooling nitrogen from the air reactor was found to be $-120.39 \mathrm{~kJ}$ (A3 and A4 $\left.-1100^{\circ} \mathrm{C}\right)$ while minimum was found to be $-52.075 \mathrm{~kJ}(\mathrm{C} 1$ $\left.-500^{\circ} \mathrm{C}\right)$.

2.7.4. Net Energy of Air Reactor. The net energy of air reactor was found by summing the energies of air preheating, air reactor enthalpy, and nitrogen stream cooling energy at respective conditions and is shown in Figure 8. It was observed that the trend of net energy of air reactor was similar to that of air reactor enthalpy already discussed in the earlier 
TABLE 3: Comparison of net energy obtainable from direct combustion and gasification coupled CLC of coal.

\begin{tabular}{|c|c|c|c|c|c|c|c|c|c|c|}
\hline Case & $\mathrm{C} 3$ & $\mathrm{C} 1$ & $\mathrm{C} 5$ & B5 & B3 & $\mathrm{B} 2$ & $\mathrm{C} 2$ & B1 & $\mathrm{C} 4$ & B4 \\
\hline $\operatorname{HCCT}\left({ }^{\circ} \mathrm{C}\right)$ & 650 & 500 & 700 & 750 & 700 & 650 & 600 & 600 & 650 & 700 \\
\hline Air required (moles) & 3.76 & 3.76 & 3.76 & 3.76 & 3.76 & 3.76 & 3.76 & 3.76 & 3.76 & 3.76 \\
\hline Preheating of coal (kJ) & 10.06 & 7.09 & 11.11 & 12.19 & 11.11 & 10.06 & 9.04 & 9.04 & 10.06 & 11.11 \\
\hline Energy to heat air (kJ) & 90.20 & 67.69 & 97.80 & 105.45 & 97.80 & 90.20 & 82.65 & 82.65 & 90.25 & 97.80 \\
\hline $\begin{array}{l}\text { Reaction enthalpy from direct } \\
\text { combustion }(\mathrm{kJ})\end{array}$ & -394.44 & -394.11 & -394.54 & -394.65 & -394.54 & -394.44 & -394.33 & -394.33 & -394.44 & -394.54 \\
\hline Energy to cool $\mathrm{N}_{2}(\mathrm{~kJ})$ & -69.95 & -52.60 & -75.81 & -81.71 & -75.81 & -69.95 & -64.13 & -64.13 & -69.95 & -75.81 \\
\hline Energy to cool $\mathrm{CO}_{2}(\mathrm{~kJ})$ & -29.56 & -21.78 & -32.22 & -34.91 & -32.22 & -29.56 & -26.93 & -26.93 & -29.56 & -32.22 \\
\hline $\begin{array}{l}\text { Net energy from direct } \\
\text { combustion }(\mathrm{kJ})\end{array}$ & -393.68 & -393.71 & -393.66 & -393.63 & -393.66 & -393.68 & -393.69 & -393.69 & -393.68 & -393.66 \\
\hline $\begin{array}{l}\text { Net energy from gasification } \\
\text { coupled CLC process }(\mathrm{kJ})\end{array}$ & -390.16 & -389.07 & -388.46 & -388.43 & -388.35 & -388.34 & -388.24 & -388.17 & -388.16 & -388.02 \\
\hline Energy Difference(kJ) & 3.52 & 4.64 & 5.20 & 5.20 & 5.31 & 5.34 & 5.46 & 5.53 & 5.52 & 5.64 \\
\hline
\end{tabular}

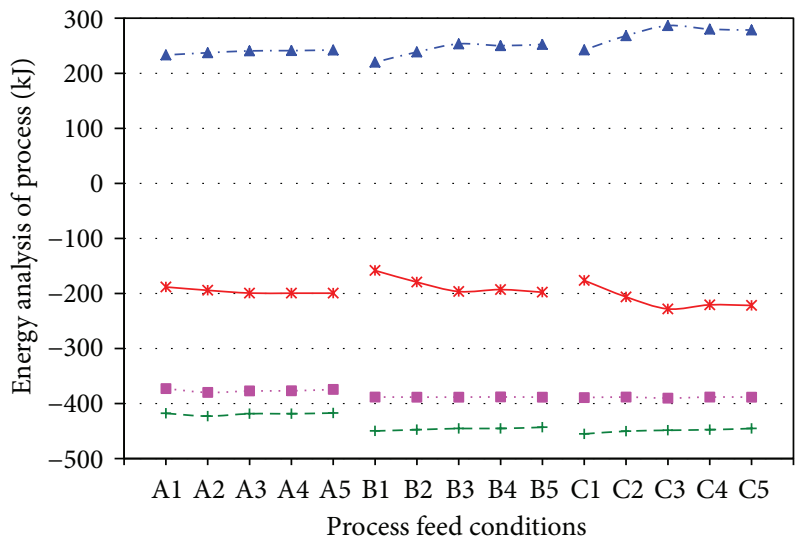

- - Gasifier total energy $\quad-+-$ Air reactor total energy

FIGURE 9: Trend of net process energy.

section. The maximum exothermicity of air reactor was found to be $-455.128 \mathrm{~kJ}$ (case $\mathrm{C} 1$ ) at $500^{\circ} \mathrm{C}$, while the minimum was observed to be $-417.22 \mathrm{~kJ}$ (case A5). It was seen that the exothermicity of air reactor for DG cases (A5, B5, C5) increased with increase in CCR while the exothermicity of air reactor increased with increase in GaCR from 1 to 3 (cases $\mathrm{A} 3, \mathrm{~B} 3$, and C3) for equimolar input of $\mathrm{H}_{2} \mathrm{O}$ and $\mathrm{CO}_{2}$.

2.8. Net Process Energy. Net energy of the process is the sum of individual energies of process components (gasifier, fuel, and air reactor). The net energy obtainable from the process at $1 \mathrm{bar}$ pressure and respective HCCTs were calculated for the different feed conditions (A1 to C5) and are shown in Figure 9. The maximum exothermicity for the whole process was found to be $-390.157 \mathrm{~kJ}$ for case $\mathrm{C} 3\left(650^{\circ} \mathrm{C}\right)$, while the minimum exothermicity was found to be $-372.82 \mathrm{~kJ}$ for case $\mathrm{A} 1$ at $1000^{\circ} \mathrm{C}$. The net energy obtainable from the process was always low for $\mathrm{GaCR}=1$ cases $(\mathrm{A} 1-\mathrm{A} 5)$ due to relative high HCCTs. The preferred conditions for process operation ranged as follows: C3 $(-390.157 \mathrm{~kJ}), \mathrm{C} 1 \quad(-389.07 \mathrm{~kJ})$,
C5 $(-388.457 \mathrm{~kJ})$, B5 $(-388.43 \mathrm{~kJ})$, B3 $(-388.349 \mathrm{~kJ})$, B2 $(-388.341 \mathrm{~kJ}), \quad$ C2 $\quad(-388.24 \mathrm{~kJ}), \quad$ B1 $\quad(-388.165 \mathrm{~kJ}), \quad \mathrm{C} 4$ $(-388.16 \mathrm{~kJ})$, and B4 $(-388.02 \mathrm{~kJ})$. The difference in energies looks small as the calculations are based on $1 \mathrm{~mol}$ coal feed but these differences will become huge for a pilot plant operation. A detailed comparison of process energy calculations of gasification coupled CLC and direct air oxidation of coal was also done and is presented in Table 3. The methodology for the direct oxidation calculations was the same, that is, preheating carbon and air to reaction temperature (HCCT), combustion enthalpy, energy obtainable by cooling product $\mathrm{CO}_{2}$ and $\mathrm{N}_{2}$, and net process energy. It was observed that the energy obtainable in direct coal combustion was slightly higher $(3-6 \mathrm{~kJ})$ than the corresponding cases of gasification coupled CLC. Thus the magnitude of net energy obtainable in gasification coupled CLC process and direct coal combustion process was found to be of similar nature. But the gasification coupled CLC process delivered an almost pure $\mathrm{CO}_{2}$ stream for sequestration making it clean energy process.

\section{Conclusions}

This theoretical systematic process study was done to understand the material and energy balances of the new process design of gasification coupled CLC of coal. The comprehensive study considered the effect of temperature, pressure and combined gasification using steam and $\mathrm{CO}_{2}$ on the process in steps. It was concluded that coal (carbon) gasification using $1.5 \mathrm{~mol} \mathrm{H}_{2} \mathrm{O}$ and $1.5 \mathrm{~mol} \mathrm{CO}_{2}$ per mole carbon at 1 bar pressure and $650^{\circ} \mathrm{C}$ delivered maximum energy from the process. The other process conditions yielding near maximum energies are also identified and can be used as necessary. The results obtained in this detailed study can be used for scale up of the process. Experimental evaluation will be helpful to further enhance the technology commercialization prospect. Use of gasification step in this study can also help design similar processes using other fuels such as natural gas, which can be converted to syngas (via steam/dry reforming) and then used in CLC processes. The CLC processes may ultimately become limited to syngas-CLC, which will help 
the OC development and reactor design aspects and ensure fast track commercialization. This process scheme has an exothermic syngas fuel reactor which may help solve many heat transfer problems in the CLC systems. Further studies using this process design and actual conditions like coal compositions, incomplete coal conversion in the gasifier, process heat losses, different reactor operating temperatures and pressures, operating energies of intermediate process equipments, for example, gas solid separators, and so forth can also be evaluated to generate data to help design practical coal CLC systems.

\section{References}

[1] E. Shoko, B. McLellan, A. L. Dicks, and J. C. D. da Costa, "Hydrogen from coal: production and utilisation technologies," International Journal of Coal Geology, vol. 65, no. 3-4, pp. 213-222, 2006.

[2] G. Tsatsaronis, K. Kapanke, and A. M. B. Marigorta, "Exergoeconomic estimates for a novel zero-emission process generating hydrogen and electric power," Energy, vol. 33, no. 2, pp. 321-330, 2008.

[3] A. Hesenov, H. Kinik, G. Puli, B. Gözmen, S. Irmak, and O. Erbatur, "Electrolysis of coal slurries to produce hydrogen gas: relationship between $\mathrm{CO}_{2}$ and $\mathrm{H} 2$ formation," International Journal of Hydrogen Energy, vol. 36, no. 9, pp. 5361-5368, 2011.

[4] S. Lin, M. Harada, Y. Suzuki, and H. Hatano, "Hydrogen production from coal by separating carbon dioxide during gasification," Fuel, vol. 81, no. 16, pp. 2079-2085, 2002.

[5] M. Abdollahi, J. Yu, K. T. L. Paul, R. Ciora, M. Sahimi, and T. T. Tsotsis, "Hydrogen production from coal-derived syngas using a catalytic membrane reactor based process," Journal of Membrane Science, vol. 363, no. 1-2, pp. 160-169, 2010.

[6] A. Martinez, K. Gerdes, G. Randall, and J. Poston, "Thermodynamic analysis of interactions between Ni-based solid oxide fuel cells (SOFC) anodes and trace species in a survey of coal syngas," Journal of Power Sources, vol. 195, no. 16, pp. 5206-5212, 2010.

[7] S. Ghosh and S. De, "Energy analysis of a cogeneration plant using coal gasification and solid oxide fuel cell," Energy, vol. 31, no. 2-3, pp. 345-363, 2006.

[8] R. S. Christopher and M. Alejandro, "Fundamental investigation of NOx formation during oxy-fuel combustion of pulverized coal," Proceedings of the Combustion Institute, vol. 33, pp. 1723-1730, 2011.

[9] M. Hishida, M. Fumizawa, Y. Inaba et al., "Nuclear energy conversion systems for arresting global warming," Energy Conversion and Management, vol. 38, no. 10-13, pp. 1365-1375, 1997.

[10] Wmo Greenhouse Gas Bulletin, No 7, World Meterological Organization, 2011.

[11] A. Abad, T. Mattisson, A. Lyngfelt, and M. Rydén, "Chemicallooping combustion in a $300 \mathrm{~W}$ continuously operating reactor system using a manganese-based oxygen carrier," Fuel, vol. 85, no. 9, pp. 1174-1185, 2006.

[12] H. Jin and M. Ishida, "A new type of coal gas fueled chemicallooping combustion," Fuel, vol. 83, no. 17-18, pp. 2411-2417, 2004.

[13] A. Lyngfelt, B. Leckner, and T. Mattisson, "A fluidized-bed combustion process with inherent $\mathrm{CO}_{2}$ separation; application of chemical-looping combustion," Chemical Engineering Science, vol. 56, no. 10, pp. 3101-3113, 2001.

[14] J. S. Dennis, C. R. Müller, and S. A. Scott, "In situ gasification and $\mathrm{CO}_{2}$ separation using chemical looping with a $\mathrm{Cu}$-based oxygen carrier: performance with bituminous coals," Fuel, vol. 89, no. 9, pp. 2353-2364, 2010.

[15] M. M. Hossain and H. I. de Lasa, "Chemical-looping combustion (CLC) for inherent $\mathrm{CO}_{2}$ separations-a review," Chemical Engineering Science, vol. 63, no. 18, pp. 4433-4451, 2008.

[16] Y. Cao and W. P. Pan, "Investigation of chemical looping combustion by solid fuels. 1. Process analysis," Energy and Fuels, vol. 20, no. 5, pp. 1836-1844, 2006.

[17] T. Mattisson, A. Lyngfelt, and H. Leion, "Chemical-looping with oxygen uncoupling for combustion of solid fuels," International Journal of Greenhouse Gas Control, vol. 3, no. 1, pp. 11-19, 2009.

[18] W. Xiang, S. Wang, and T. Di, "Investigation of gasification chemical looping combustion combined cycle performance," Energy and Fuels, vol. 22, no. 2, pp. 961-966, 2008.

[19] M. Zheng, L. Shen, and J. Xiao, "Reduction of $\mathrm{CaSO}_{4}$ oxygen carrier with coal in chemical-looping combustion: effects of temperature and gasification intermediate," International Journal of Greenhouse Gas Control, vol. 4, no. 5, pp. 716-728, 2010.

[20] L. Shen, J. Wu, and J. Xiao, "Experiments on chemical looping combustion of coal with a NiO based oxygen carrier," Combustion and Flame, vol. 156, no. 3, pp. 721-728, 2009.

[21] X. Wang, B. Jin, W. Zhong, Y. Zhang, and M. Song, “Threedimensional simulation of a coal gas fueled chemical looping combustion process," International Journal of Greenhouse Gas Control, vol. 3, pp. 1750-5836, 2011.

[22] J. Corella, J. M. Toledo, and G. Molina, "Steam gasification of coal at low-medium $\left(600-800^{\circ} \mathrm{C}\right)$ temperature with simultaneous $\mathrm{CO}_{2}$ capture in a bubbling fluidized bed at atmospheric pressure. 2. Results and recommendations for scaling up," Industrial and Engineering Chemistry Research, vol. 47, no. 6, pp. 1798-1811, 2008.

[23] J. Matsunami, S. Yoshida, Y. Oku, O. Yokota, Y. Tamaura, and M. Kitamura, "Coal gasification by $\mathrm{CO}_{2}$ gas bubbling in molten salt for solar/fossil energy hybridization," Solar Energy, vol. 68, no. 3, pp. 257-261, 2000.

[24] M. F. Irfan, M. R. Usman, and K. Kusakabe, "Coal gasification in $\mathrm{CO}_{2}$ atmosphere and its kinetics since 1948: a brief review," Energy, vol. 36, no. 1, pp. 12-40, 2011.

[25] D. P. Ye, J. B. Agnew, and D. K. Zhang, "Gasification of a South Australian low-rank coal with carbon dioxide and steam: kinetics and reactivity studies," Fuel, vol. 77, no. 11, pp. 1209-1219, 1998.

[26] A. Molina and F. Mondragón, "Reactivity of coal gasification with steam and $\mathrm{CO}_{2}$," Fuel, vol. 77, no. 15, pp. 1831-1839, 1998.

[27] C. Nenad, R. Branislav, M. Rastko, N. Olivera, and V. Miomir, "Experimental investigation of role of steam in entrained flow coal gasification," Fuel, vol. 86, no. 1-2, pp. 194-202, 2007.

[28] A. Abad, F. G. Labiano, L. F. de Diego, P. Gayán, and J. Adánez, "Reduction kinetics of $\mathrm{Cu}-$, $\mathrm{Ni}-$, , and $\mathrm{Fe}$-based oxygen carriers using syngas $\left(\mathrm{CO}+\mathrm{H}_{2}\right)$ for chemical-looping combustion," Energy and Fuels, vol. 21, no. 4, pp. 1843-1853, 2007.

[29] T. Mattisson, F. G. Labiano, B. Kronberger, A. Lyngfelt, J. Adánez, and H. Hofbauer, "Chemical-looping combustion using syngas as fuel," International Journal of Greenhouse Gas Control, vol. 1, no. 2, pp. 158-169, 2007.

[30] S. P. Singh, S. A. Weil, and S. P. Babu, "Thermodynamic analysis of coal gasification processes," Energy, vol. 5, no. 8-9, pp. 905-914, 1979. 
[31] M. Gassner and F. Maréchal, "Thermodynamic comparison of the FICFB and Viking gasification concepts," Energy, vol. 34, no. 10, pp. 1744-1753, 2009.

[32] Z. Wang, J. Zhou, Q. Wang, J. Fan, and K. Cen, "Thermodynamic equilibrium analysis of hydrogen production by coal based on $\mathrm{Coal} / \mathrm{CaO} / \mathrm{H}_{2} \mathrm{O}$ gasification system," International Journal of Hydrogen Energy, vol. 31, no. 7, pp. 945-952, 2006.

[33] M. Díaz-Somoano and M. R. Martínez-Tarazona, "Trace element evaporation during coal gasification based on a thermodynamic equilibrium calculation approach," Fuel, vol. 82, no. 2, pp. 137-145, 2003.

[34] A. Dufaux, B. Gaveau, R. Létolle, M. Mostade, M. Noël, and J. P. Pirard, "Modelling of the underground coal gasification process at Thulin on the basis of thermodynamic equilibria and isotopic measurements," Fuel, vol. 69, no. 5, pp. 624-632, 1990.

[35] X. Li, J. R. Grace, A. P. Watkinson, C. J. Lim, and A. Ergüdenler, "Equilibrium modeling of gasification: a free energy minimization approach and its application to a circulating fluidized bed coal gasifier," Fuel, vol. 80, no. 2, pp. 195-207, 2001.

[36] A. Melgar, J. F. Pérez, H. Laget, and A. Horillo, "Thermochemical equilibrium modelling of a gasifying process," Energy Conversion and Management, vol. 48, no. 1, pp. 59-67, 2007.

[37] Y. Cao and W. P. Pan, "Investigation of chemical looping combustion by solid fuels. 1. Process analysis," Energy and Fuels, vol. 20, no. 5, pp. 1836-1844, 2006.

[38] J. P. E. Cleeton, C. D. Bohn, C. R. Müller, J. S. Dennis, and S. A. Scott, "Clean hydrogen production and electricity from coal via chemical looping: identifying a suitable operating regime," International Journal of Hydrogen Energy, vol. 34, no. 1, pp. 1-12, 2009.

[39] Z. P. Gao, L. Shen, J. Xiao, C. Qing, and Q. Song, "Use of coal as fuel for chemical-looping combustion with $\mathrm{Ni}$-based oxygen carrier," Industrial \& Engineering Chemistry Research, vol. 47, pp. 9279-9287, 2008.

[40] HSC Chemistry [software], Version 5. 1. Pori, Outokumpu Research Oy, 2002.

[41] W. R. Smith, "Computer software reviews," Journal of Chemical Information and Computer Sciences, vol. 36, no. 1, pp. 151-152, 1996, HSC Chemistry for Windows, 2.

[42] R. H. Perry and D. W. Green, Chemical Engineers'Handbook, McGraw-Hill, 7th edition, 1997. 

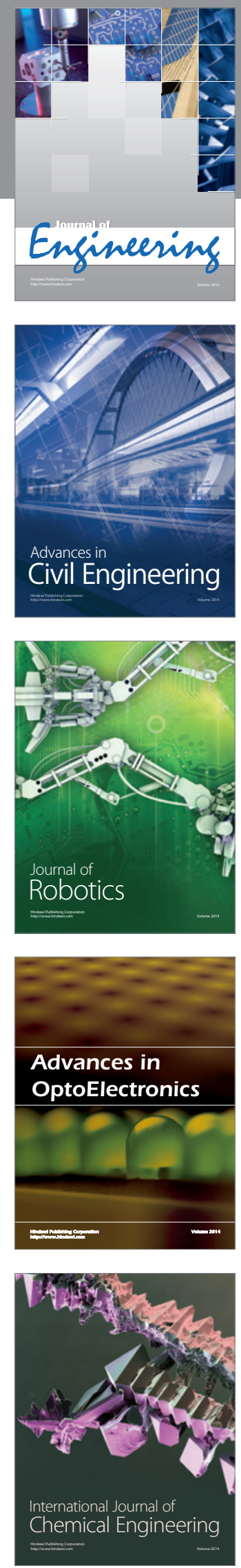

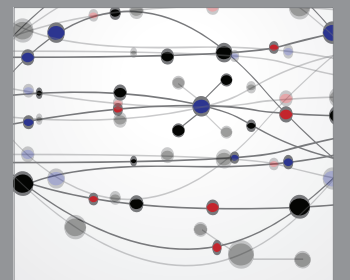

The Scientific World Journal
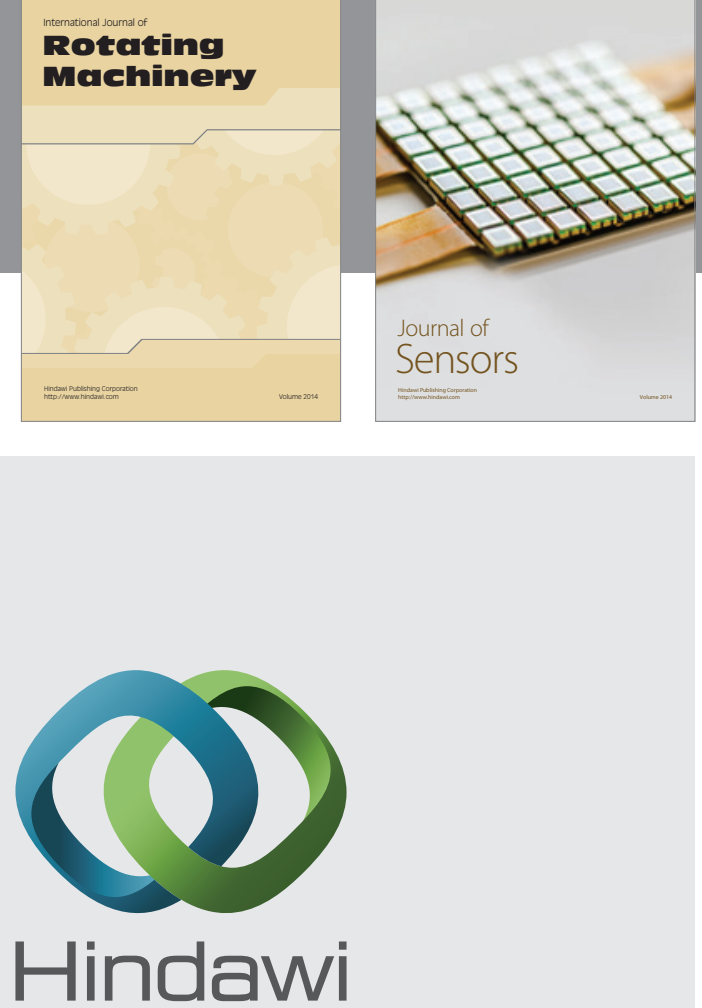

Submit your manuscripts at http://www.hindawi.com
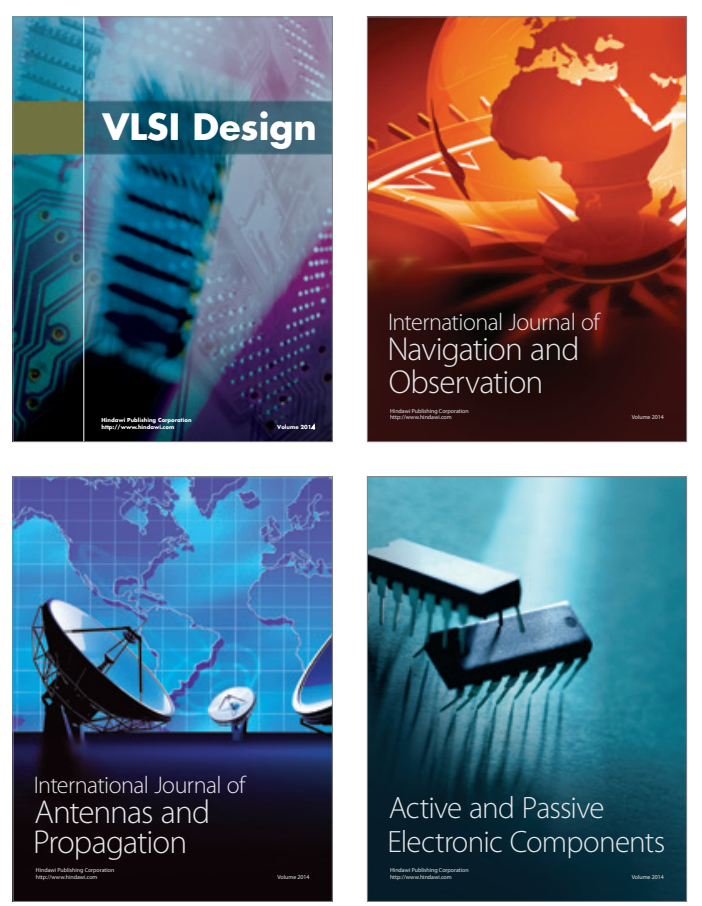
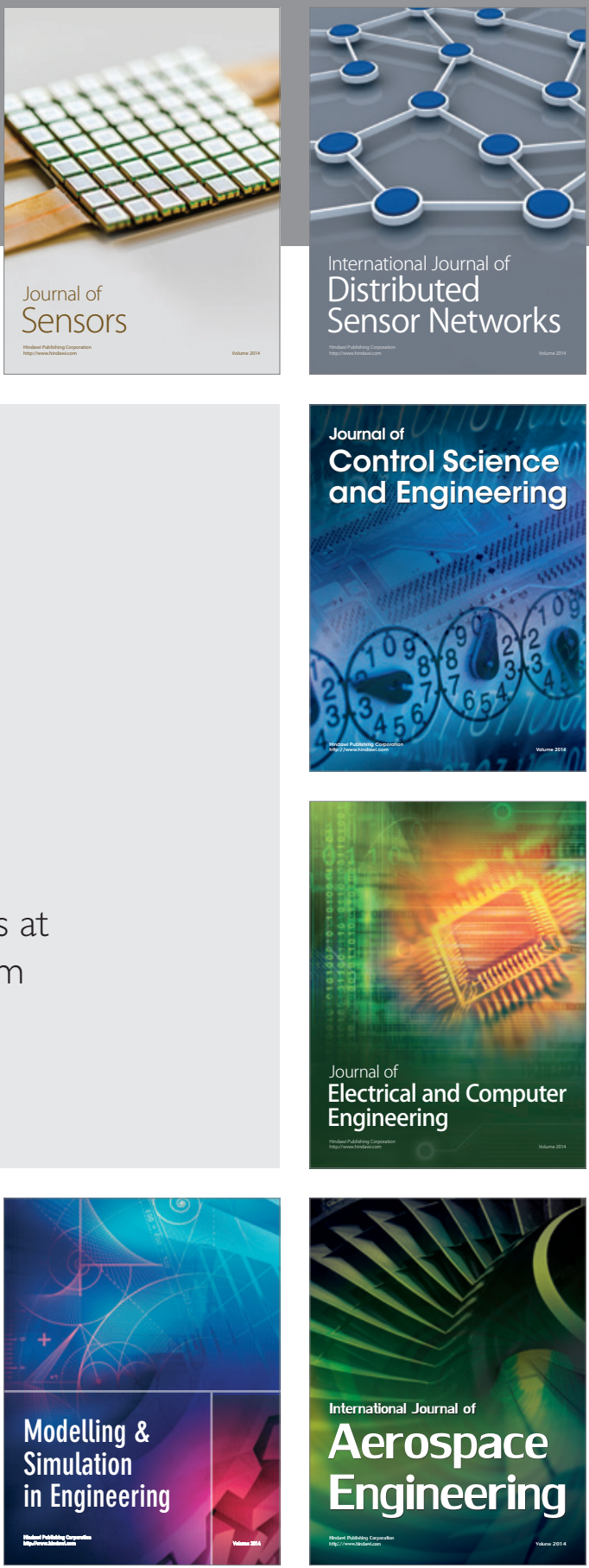

Journal of

Control Science

and Engineering
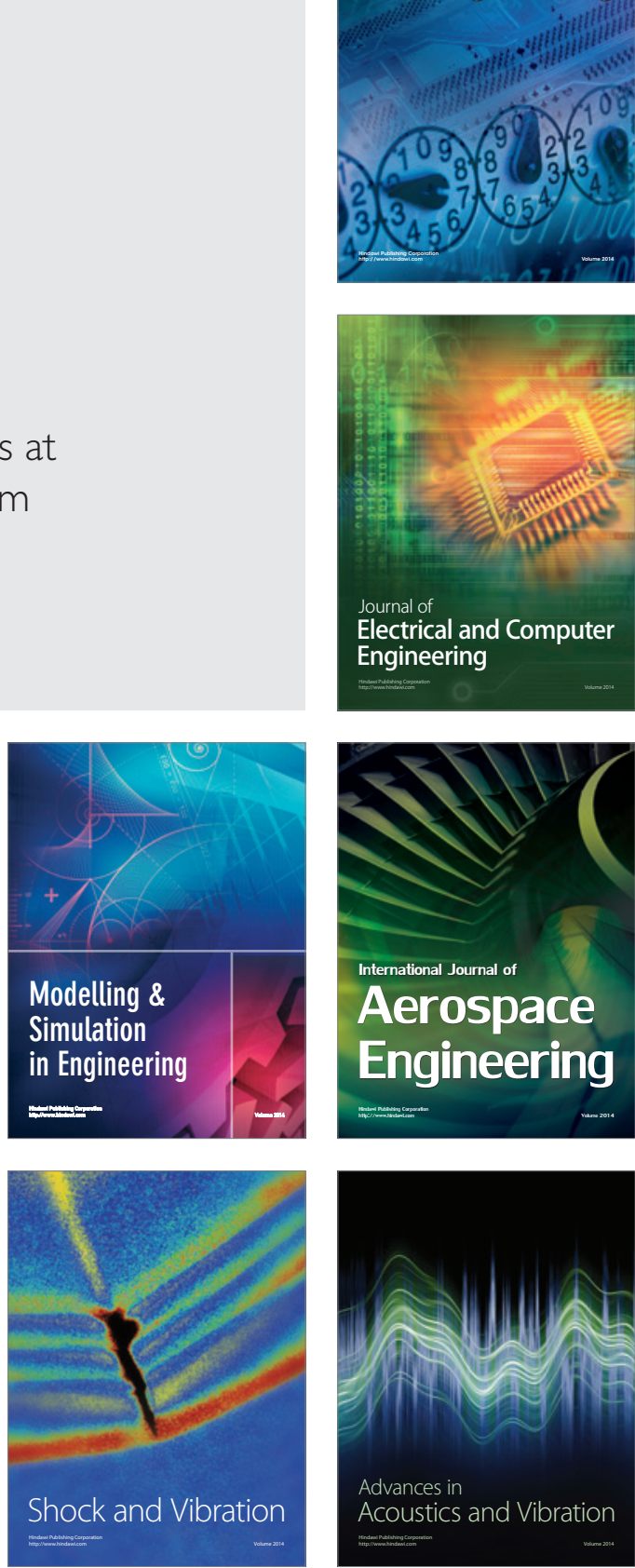